\title{
Covid-19 Pandemisinin Katılım Endeksi Üzerindeki Etkisinin Analizi ${ }^{1}$
}

\section{The Effect of Covid-19 Outbreak on Participation (Islamic) Index}

\author{
Muhammet Fatih CANBAZ ${ }^{2} *$ \& Ender BAYKUT ${ }^{3}$
}

Geliş / Received: 13/10/2021

Revize / Revised:10/11/2021

Kabul / Accepted: 11/11/2021

\begin{abstract}
$\overline{\mathbf{O Z Z}}$
Korona virüs pandemisi ülke ekonomileri gibi finansal piyasaları da derinden etkilemiştir. Özellikle Mart 2020'de Dünya Sağlık Örgütü’nün korona virüs hastalığını küresel bir pandemi ilan etmesinden sonra piyasalarda yüksek oynaklıklar gözlenmeye başlanmıştır. Gelişen ülke borsalarında günlük \%12'lik düşüşlerin tespiti uluslararası borsaları daha da ağır etkilemiştir. Borsada işlem gören ve yüksek borçluluk yapısına sahip şirketler, özkaynak ağırlıklı şirketlere nazaran daha fazla volatiliteye maruz kalmışlardır. Bu noktada, faizli işlemleri olmayan veya bilançosunda çok düşük bir paya sahip olan Katılım Endeksi şirketlerinin pandemi sürecinden daha az etkilenmesi gerektiği düşünülmüştür. Bu çalışmada, Katılım-30 (KATLM-30) Endeksi'nin, Mart 2020-Aralık 2020 dönemine iliş̧kin günlük kapanış verileri üzerinden analizler yapılmışstır. Korona virüs verilerinin, KATLM-30 Endeksi üzerindeki etkisinin tespit edilmesi amacıyla yapılan çalışmada, günlük vaka sayısı, günlük korona virüs kaynaklı vefat sayısı ve günlük iyileşen hasta sayısı bağımsız değişken olarak ele alınmıştır. ARDL modelinin en uygun model olarak belirlendiği çalışma bulgularına göre, KATLM-30 Endeksi ile korona virüs verileri arasında uzun dönemli ilişki mevcuttur.
\end{abstract}

Anahtar Kelimeler- Katılım Endeksi, Covid-19, Sermaye Piyasaları, Etki

\begin{abstract}
The coronavirus pandemic has deeply affected the financial markets as well as economies. Especially after the 20th of March, 2020 when World Health Organization declared coronavirus disease as a global pandemic, high volatility began to be observed in the financial markets. $12 \%$ decrease which occurred in the stock markets of the developing countries caused even heavier loses in the developed countries stock markets. The listed companies at stock market with high borrowing rates faced more volatility comparing to equity-based companies. The companies listed on the participation index that has no interest obligations or having interest obligations that has a low share in their balance sheets being less affected from the pandemic is one of the expected results. This research was conducted by analyzing the daily closing data of KATLM-30 index, and the data belongs to the period of March 2020 - December 2020. The purpose of this research is investigating the effect of COVID numbers on KATLIM-30 index by using the number of daily cases, number of daily deaths from the virus, and the daily number of people that had the virus and recovered used as independent variable. It is decided that ARDL model is the best fitted for the analysis and according to the results, there is a long-term relationship between the KATLM30 index and the coronavirus numbers.
\end{abstract}

Keywords- Islamic Indices, Covid-19, Capital Markets, Effect

\footnotetext{
${ }^{1} \mathrm{Bu}$ çalışma, 21-24 Eylül 2021 tarihlerinde düzenlenen "ICISEF 2021: Rethinking the Developmental Role of Islamic Economy and Finance: New Horizons" başlıklı kongrede, Ender AYKUT ve Muhammet Fatih CANBAZ tarafindan sunulan "Covid-19 Pandemisinin Katilim-30 Endeksi Üzerindeki Etkisinin Analizi” başlıklı bildiriden üretilmiştir.

2 *Sorumlu Yazar, Dr. Öğr. Üyesi, Bolu Abant İzzet Baysal Üniversitesi, Gerede Uygulamalı Bilimler Fakültesi, Finans ve Bankac1lık Bölümü, muhammetfatih.canbaz@ibu.edu.tr, (https://orcid.org/0000-0002-4711-3489)

3 Doç. Dr., Afyon Kocatepe Üniversitesi, İktisadi ve İdari Bilimler Fakültesi, İşletme Bölümü, ebaykut@aku.edu.tr, (https://orcid.org/0000-0002-3908-4008)
} 


\section{GíRiş}

Korona virüs (COVID-19) salgın süreci dünya ekonomileri açısından ciddi bir sınav olurken reel sektörü ve finans sektörünü önemli ölçüde olumsuz etkilemiştir. Tüm dünyada işletmelerin üretimlerini durdurmalarına, ithalat ve ihracatta kısıtlamalara, zorunlu olarak kepenk indirmelere ve tüketimin azalmasına yol açmıştır. Korona virüs salgınına karşı uygulanan kısıtlamalar nedeniyle çok sayıda kişi işini kaybetmiş ve aile ekonomisinde büyük düşüşler yaşanmıştır. Gelişmiş ülkeler de dâhil olmak üzere birçok ülkede işsizlik oranları ciddi seviyelere ulaşmıştır. Salgından en çok etkilenen turizm ve hizmet sektörü başta olmak üzere, istihdam kaybını önlemek adına yönetimler tarafından birçok sektöre yönelik ödenekler ve sair destekler sağlanmıştır. Diğer taraftan ev ortamında icra edilebilen iş modelleri ve internet aracılığıyla hizmet veren sektörler salgın sürecinden pozitif olarak etkilenmişlerdir. Bunların başında e-ticaret, uzaktan eğitim, kargo, ulusal market zincirleri, hobi, internet ile TV platformları gelmektedir. Bu kanaati destekleyen bir araştırma olan ve Deloitte bağımsız denetim şirketi tarafından hazırlanan "Küresel Covid-19 Salgınının Türkiye'de Farklı Kategorilere Etkileri” adlı rapor kamuoyuna sunulmuştur. İlgili rapora göre salgın sürecinden pozitif ve negatif etkilenen sektörler Grafik 1'de gösterilmiştir.

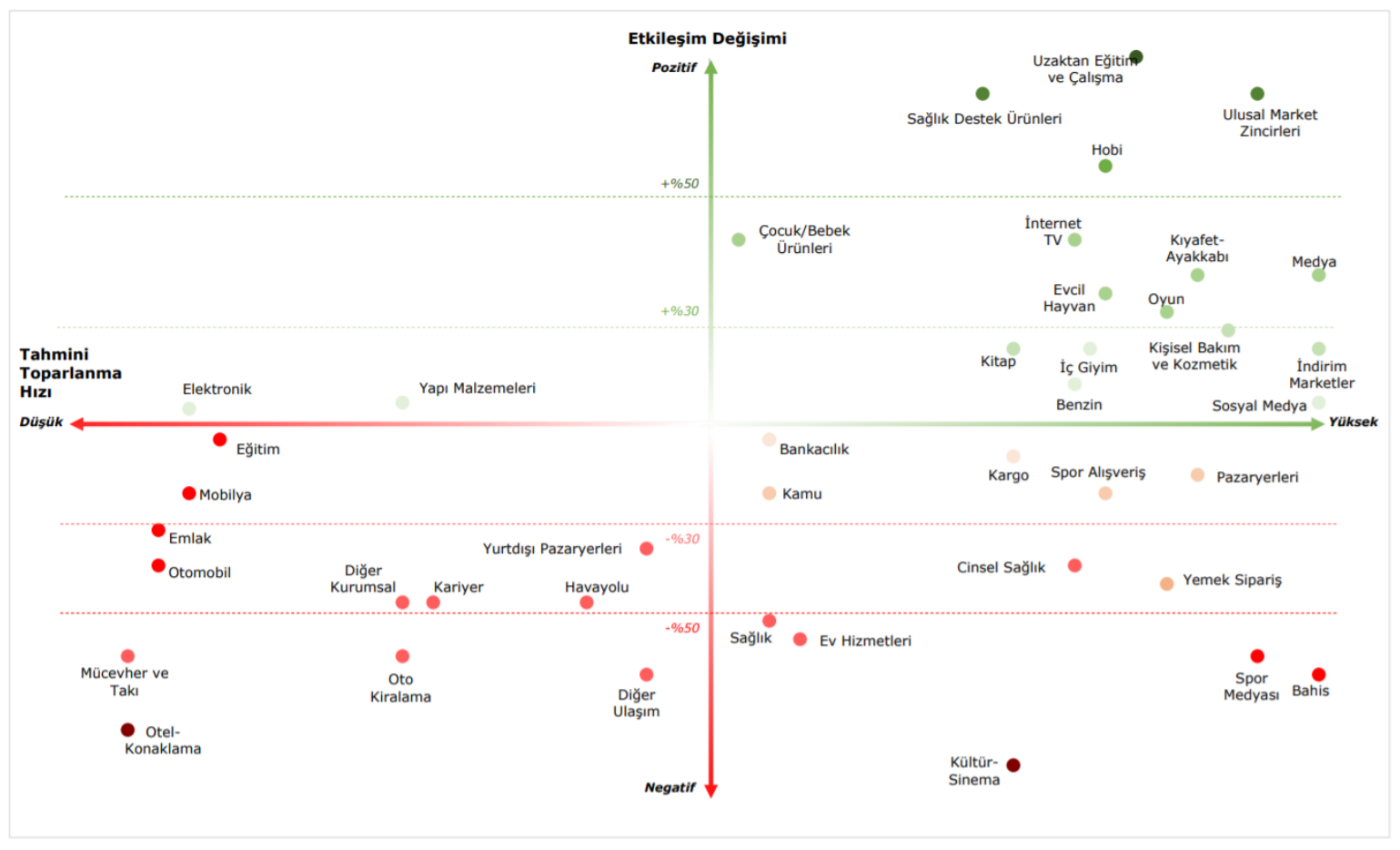

Grafik 1. Türkiye'de Covid-19 Salgınında Sektörlerin Etkileşim Değişimi ve Tahmini Toparlanma Hızları, Mart 2020

Kaynak: (Deloitte, 2020: 2)

Grafikten de anlaşılacağı üzere pandemi özellikle insanların bir araya gelmesini gerektiren iş modellerini ve sektörleri etkilemiştir. Yukarıda vurgulanan sektörlerin yanında finansal piyasalarda ve hisse senetlerinin alınıp satıldığı borsalarda da güven ortamının bozulmasına bağlı olarak büyük değişimler yaşanmıştır. Bu durum emeklilik fonlarının değerini ve bireysel tasarruf hesaplarını da olumsuz etkilemiştir. Covid-19 sürecinde vaka sayıları artarken Londra'daki FTSE borsası, New York Wall Street'teki Dow Jones Endeksi ve Japonya'daki Nikkei endeksinde büyük düşüşler yaşanmıştır. 2020'nin ilk çeyreğinde Dow Jones ve FTSE, 1987'deki ilk çeyrekten sonraki en büyük düşüşü görmüştür. Durumu normalleştirmek için birçok ülke tüketici harcamalarını arttırmak adına kredi maliyetlerini düşürmüş ekonomiyi canlandırmak amacıyla merkez bankaları faiz oranlarını indirmiştir. Hükümetlerin müdahalesi ile küresel piyasalarda kısmi iyileşmeler görülse de salgında ikinci ve üçüncü dalga tecrübesi, aşılanmanın beklenen seviyelerde gerçekleşmemesi hala belirli endişeleri canlı tutmakla birlikte piyasaların oynaklığını da etkilemektedir.

$\mathrm{Bu}$ süreçte yatırımcıların finansal tercihlerinde de ciddi değişimler gözlenerek yatırımcı profilinde değişimler yaşanmıştır. Türk lirasının politik ve konjonktürel nedenlerle değer kaybetmesi nedeniyle yatırımcılar altın, gümüş, emtia vb. gibi daha az riskli yatırım araçlarına ilgi duymaya başlamışlardır. Korona virüs salgın 
sürecinde yatırım fonlarından çıkışlar nedeniyle Türkiye borsası küçülmüş ancak bu küçülme, borsadan daha yüksek getiri elde edebilme ihtimalini de artırdığı için borsa yatırımcısı olma fikrini daha cazip hale getirmiştir. Normalleşme adımlarıyla beraber yatırım tutarlarında beklendiği gibi artış ve hisselerin değerlendiği görülmüştür. Pandeminin başlangıcı olan 2019 yıl sonu itibariyle borsada yatırımcı sayısı 1.203.438 kişiyken 2020 Ekim sonu itibariyle yaklaşık 671.000 artsşla 1.874.395 kişiye ulaşmıştır (Merkezi Kayıt Kuruluşu, 2020). Bu değişimde bütünüyle salgının etkisi olduğunu söylemek doğru bir yaklaşım olmamakla birlikte ciddi bir etken olduğu anlaşılmaktadır.

Son yıllarda sermaye piyasalarında artan yatırım yapma eğilimleri, piyasa yapıcıların alternatif araçlar üretme çabalarını doğurmuş̧ur. Nitekim sermaye piyasalarından İslâmi hassasiyetleri gereği uzak duran tarafların piyasalara çekilmesi amacıyla yeni ürünler ortaya konmuştur. Bu ürünlerden biri de uluslararası literatürde "shariah index" olarak ifade edilen ve ülkemizde "Katılım endeksleri" veya "İslami Endeksler" olarak kavramsallaşan portföylerdir (Çonkar, Canbaz, \& Öztürk, 2019). Ülkemizde ilk İslâmi endeks olarak nitelendirilen "Katılım 30 Endeksi" 2011 y1lı itibariyle Borsa İstanbul'da (BİST) işlem görmeye başlamıştır. İslâmi sermaye piyasası ürünlerinin, İslâm iktisadı ve finansı kaidelerine uygun ürünleri ve operasyonları içermesi gerekmektedir. $\mathrm{Bu}$ ilkeden hareketle endekste yer alacak şirketler öncelikle faaliyet alanı kriterleri açısından değerlendirilmekte ardından finansal izleme kriterlerine tabi tutulmaktadır. Her iki izleme kriterlerini karşılayabilen şirketler katılım endekslerinde kendilerine yer bulmaktadır. Endekslere dahil olan şirketler üç ayda bir mali tablo dönemlerinde tekraren bu iki izleme kriterlerine tabi tutularak güncellenmektedir. Endeksin faaliyet alanı kriterlerine göre;

- "faize dayalı finans, ticaret, hizmet, aracllı (bankacılık, sigorta, finansal kiralama, faktöring ve diğer faize dayalı faaliyet alanlarını kapsar), alkollü içecek, kumar, şans oyunu, domuz eti ve benzer gıda, basın, yayın, reklam, turizm, eğlence, tütün mamulleri, vadeli altın, gümüs ve döviz ticareti"

alanlarında faaliyet göstermeyen şirketlerden oluşmalıdır. İkinci aşama izleme kriterlerinde ise endekste yer alacak şirketlerin finansal açıdan aşağıdaki rasyoları sağlaması gerekmektedir.

- Faizli Krediler / Piyasa Değeri <\%30

Aday şirketin toplam faizli kredilerinin piyasa değerine oranı \%30'dan düşük olması

- Faiz Getirili Nakit ve Menkul Ktymetler / Piyasa Değeri <\%30

Aday şirketin faiz getirisi sağlayan nakit ve menkul klymetlerinin piyasa değerine oranı \%30'dan düşük olmasl

\section{- Uygun Olmayan Sektörlerden Elde Edilen Gelirler / Toplam Gelir $<\% 5$}

Haram veya uygun olmayan sektörlerden elde edilen gelirlerinin toplam gelire oranı \%5'ten düşük olması (BMD, 2021)

Katılım finans sisteminin yeni sayılabilecek araçlarından olan katılım endekslerinin katılım bankacılığının geçmiş performansından hareketle finansal kriz dönemlerinde geleneksel endekslere nazaran daha dirençli olacağ 1 yönünde genel bir öngörü bulunmaktadır. Bu çalışma ile Covid-19 salgın döneminde ilgili endekslerin nasıl bir dalgalanma yaşadığı ve süreçten nasıl etkilendiği araştırılmıştır. Çalışma, sonuçları itibariyle katılım endekslerinde listelenen şirketlere yatırım yapan tarafların olumlu kabullerinin test edilmesi ve katılım endekslerine yatırım yapma kararı alacak taraflara ise erken aşamada bilgi akışı sağlayacaktır.

\section{LITERATÜR TARAMASI}

Korona virüs toplum sağlı̆̆ını etkilediği gibi finansal piyasaları ve ülkeleri de aynı ölçüde etkilemiştir. Her ne kadar uzun yıllara sâri bir deneyim olmasa da korona virüsün finansal piyasalar ve ekonomiler üzerindeki etkisine yönelik çalışma sayısı günden güne artmaktadır. Bu çalışmalar gerek mikro düzeyde gerekse makro düzeyde etkileri ortaya çıkarmak maksadıyla yapılmaktadır. Çalışma kapsamında ele alınan korona virüsün katılım endeksi üzerindeki etkileri, Türkiye'de sınırlı sayıda çalışmada ele alınmıştır. Bu açıdan çalışma literatürdeki bu boşluğu doldurmayı hedeflemektedir. Literatür taraması yapılırken sistematik bir yol izlenerek ilk önce korona virüsün küresel piyasalar üzerindeki etkisini ele alan çalışmalara, daha sonra ise Türkiye finansal piyasaları ve ekonomisi üzerindeki etkiyi araştıran çalışmalara odaklanılmıştır. Son aşamada korona virüs ve katılım endeksini değişken olarak ele alan çalışmalar raporlanmıştır.

Sherif (2020) çalışmasında korona virüsün (COVID-19) hızlı yayılmasının Şeriat uyumlu İngiltere Dow Jones piyasa endeksi üzerindeki kısa vadeli etkilerini araştırmıştır. 20 Ocak- 20 Mayıs dönemine ait günlük verileri 
ve İngiltere'deki on endüstriyel sektör verileri kullanılmıştır. Sonuçlar COVID-19 salgını ile geleneksel borsa endeksinin performansı arasında güçlü ve istatistiksel olarak anlamlı bir ilişki olduğunu göstermektedir. Salgın süreci İngiltere Dow Jones İslâmi endeksini olumsuz şekilde etkilerken geleneksel muadillerine kıyasla etkini önemsiz olduğu tespit edilmiştir. Ek olarak, sektörler özelinde yapılan analizde bilgi teknolojileri sektörünün hisse senedi getirileri çok daha iyi performans gösterirken, ulaşım, içecek, turizm ve eğlence sektörlerinin hisse senedi getirileri önemli ölçüde daha kötü performans göstermiştir. Baek vd. (2020) ise korona virüsün, ABD borsas1 üzerindeki etkisini ve oynaklığını endüstri düzeyinde analiz etmiştir. Markov Switching AR modeli kullanılarak yapılan araştırma sonucunda oynaklığın belirli ekonomik göstergelerden etkilendiğini ancak COVID-19 haberlerine daha duyarlı olduğu tespit edilmiştir. Oynaklık hem olumsuz hem de olumlu COVID-19 bilgilerinden etkilenirken olumsuz haberlerin daha ciddi etkiler bıraktığı görülmüştür. Yanı sıra yazarlar piyasalarda olumsuzluk önyargısı olduğunu düşünmektedirler. Tüm sektörlerde toplam ve kendine özgü riskte önemli artışlar gözlemlenirken, sistematik riskteki değişiklikler endüstrilere göre farklılık göstermektedir. Baker vd. (2020) değişkenler olarak hisse senedi piyasası oynaklığı, ekonomik belirsizlik ve işgücü piyasaları üzerinden pandeminin ABD ekonomisindeki finansal etkilerini araştırmışlardır. Araştırma sonuçlarına göre seyahat kısıtlamalarının, iş yeri kapatmaların ve sosyal mesafenin büyük ekonomik zararlara yol açı̆̆ı savunulmaktadır. Yanı sıra Ülkenin 2020 son çeyreğinde \%11-20 arasında bir küçülmeyle karşılaşacağını ifade edilmiştir. Ve bu küçülmenin \%50'sinin pandemi nedeniyle ortaya çıkan belirsizliklere dayalı olduğu vurgulanmıştır. Alber (2020) pandeminin borsalar üzerindeki etkilerini 6 ülke piyasası üzerinden incelemiştir. Bu ülkeleri vaka açısından en kötü 6 ülke olarak tanımlamaktadır. Sırasıyla Çin, Fransa, Almanya, İtalya, İspanya ve ABD olan bu ülkeler kümülatif vaka sayısı dikkate alınarak belirlenmiştir. Yapılan araştırma sonucunda hisse senedi piyasalarının yeni vaka sayılarına ölüm rakamlarından daha duyarlı olduğunu ortaya koymuştur. Ayrıca pandemi süreci Çin, Fransa, Almanya ve İspanya piyasalarını olumsuz etkilerken ABD ve İtalya'nın süreçten olumsuz etkilendiğine dair bir bulguya ulaşılamamıştır. Ayittey vd. (2020) yapmış oldukları çalışmalarında pandeminin Çin ve Dünya ekonomisine etkilerini araştırmışlardır. Araştırma sonuçlarına göre Çin'in yılın ilk çeyreğinde 62 milyar dolara varan kayıp yaşayacağını yanı sıra dünyanın ise 280 milyar doların üzerinde muhtemel kayıp yaşayacağını öngörmüşlerdir. Bu sonuç Dünya Bankası'nın 2009 yapmış olduğu H1N1 virüsleri gibi daha zayıf bir grip salgınının bile küresel GSYH'nin \%5'ini eritebileceği tahminiyle paralellik göstermektedir. Çalışmada literatüre bezer şekilde olumsuz etkilerin uzun süreli olacağı tahmin edilmektedir. Alfaro vd. (2020) pandeminin ABD hisse senetleri getirilerini nasıl etkilediğini araştırmıştır. Araştırma sonucunda enfeksiyonun tahminlerin dışında beklenmedik şekilde katlanarak büyümesi $\mathrm{ABD}$ piyasalarında $\% 4$ ile $\% 11$ oranında değer kaybına neden olduğu tespit edilmiştir. Vakalardaki belirsizlik azaldıkça hisse senedi piyasasındaki volatilitenin de azaldığına yönelik bulgular saptanırken bu eğilimin devam etmesi gerektiği ifade edilmiştir. Yanı sıra bu sonuçlar ülkedeki rekor seviyede iş̧̧i çıkarmalar ile de ilişkilendirilmiştir. Morales ve O'Callaghan (2020) çalışmalarında korona virüsün bir "black swan" vakası olduğunu ve Nassim Nicholas Taleb'in teorisini desteklediğini ifade etmişlerdir. Çalışmada Covid-19'un dünyanın önde gelen borsaları üzerindeki etkisi, spektral nedensellik ve Granger nedensellik testi ile incelenmiştir. Temel araştırma bulguları, piyasaların Şangay borsası tarafından sergilenen oynaklık seviyelerine tepki vermediğini ve Çin'in virüs salgınının merkez üssü olarak tanımlandığını göstermektedir. Avrupa tarafında ise İtalya'nın ilk vakalarını açıklamasıyla piyasalar virüsün küresel bir tehdit olduğunu farketmiştir. Vakalarla birlikte İtalyan borsasında başlayan oynaklık yansımaları Avrupa'nın korku sürecine girmesine neden olmuştur. Albulescu (2020) COVID-19 vakaların ve ölüm oranının Amerika Birleşik Devletleri'ndeki (ABD) finansal piyasalardaki nasıl bir oynaklığa sebep olduğunu ampirik olarak araştırmıştır. Araştırma bulgularına göre hem küresel rakamların hem de ABD rakamlarının S\&P 500 üzerinde oynaklığı artırdığını tespit etmiştir. Sürecin uzaması halinde ise oynaklığın devam edeceğini öngörmektedir.

Koronavirüsün Türkiye'deki finansal piyasalar üzerindeki etkisi de çeşitli açılardan araştırmacılar tarafından analiz edilmiş̧ir. Keleş (2020) çalışmasında koronavirüsün Türkiye'de ortaya çıkma ve yayılması sürecinde hisse senedi piyasasının kısa dönemli tepkilerini araştırmışıtır. Bu kapsamda veri olarak BİST-30 endeksinde yer alan hisse senetlerinin Mart ve Nisan 2020 dönemine iliş̧in günlük fiyatları kullanılmıştır. Çalışma bulgularına göre pay piyasası vaka, ölüm ve tedbir haberlerine belirgin tepkiler vermiştir. Özellikle 100 . vaka, 1000. vaka ve 1000. ölüm haberlerine negatif tepkiler göstermiştir. Buna karşın alınan tedbirlerin pozitif etkileri beraberinde getirdiği tespit edilmiştir. Sektörler özelinde ise Otomobiller ve Bileşenleri grubu ile Taşımacılık grubunun diğer sanayi gruplarına göre en çok etkilenen taraf olduğu tespit edilmiştir. Buna karşllık, Özdemir (2020) Covid-19 pandemisinin Türkiye sektör endeksleri üzerindeki etkilerini araştırdığı çalı̧̧ma sonucunda mali sektör endeksinin süreçten olumsuz etkilendiğini teknoloji sektör endeksinin ise olumlu etkilendiğini ortaya koymuştur. Özkan (2020) tarafından yapılan çalışmada ise Covid-19 pandemisinin Türkiye hisse senedi piyasası üzerindeki etkisi incelenmiştir. Çalışmada 23 sektör endeksinin Haziran 2019 ile Temmuz 2020 arasındaki 
oynaklıklarını hesaplanmıştır. Oynaklık değerlerinin analizi sonrasında Türkiye'deki vakaların ortaya çıktığı ve hızla arttığı Mart 2020'de tüm sektör endekslerinde volatilite sıçraması olduğunu; en fazla oynaklık sıçramasının spor şirketlerinin hisselerinde, en az oynaklık sıçramasının ise sigorta firmalarının senetlerinde görüldüğü; Mart 2020'den sonra bütün sektör endekslerinin oynaklık değerlerinin normale döndüğünü ifade edilmiştir.

Koronavirüsün sektörler üzerindeki etkilerinin ele alındığı çalışmalar gibi Borsa İstanbul endeksleri üzerindeki etkisi de yoğun olarak analiz edilen bir başka çalışma konusu olarak karşımıza çıkmaktadır. Çetin (2020) koronavirüs salgınının Türkiye ekonomisi üzerindeki etkilerini, hisse senedi borsa endeksi ve genel ekonomik faaliyetler açısından analiz etmiştir. Çalışmada hisse senetlerinin fiyat performans olarak Borsa İstanbul BIST-100 endeksi, genel ekonomik faaliyetlerin düzeyini temsilen de "Satın Alma Yöneticileri Endeksi" kullanılmıştır. 23 Mart 2020- 24 Nisan 2020 tarihleri arasındaki günlük verilerle yapılan analiz sonucunda kısıtlamaların genel ekonomik faaliyetler seviyesini-0,708 birim düşürdüğünü ancak hisse senedi fiyatlarını olumsuz etkilemediğini ortaya koymuştur. Kayral ve Tandoğan (2020) BİST100 endeksi, Dolar, Euro ve altın fiyatlarına ilişkin getirilerin ve oynaklığın COVID-19 pandemisinden etkilenme düzeyleri ile bu değişkenler arasındaki oynaklığı araştırmıştır. 01.01.2015 - 08.07.2020 dönem verileri ve CCC-GARCH modeli kullanılan çalışma sonucunda COVID-19 pandemisinin BİST100 endeksi ve altın getirilerinde az da olsa artırıcı etkisinin olduğu tespit edilmiştir. Pandemi sürecinin genel olarak yatırım araçlarının volatilitelerini artırdığı tespit edilmiştir. Değişkenlerden Dolar'dan Euro'ya doğru pozitif volatilite yayılımı bulunurken, en yüksek yayılımın ABD ile yaşanan politik kriz nedeniyle 2018'de gerçekleştiği görülmüştür. Yatırım araçlarının arasındaki yayılım pandemi sürecinde sınırlı seviyede izlenmiştir. BİST100 endeksi ile altın arasındaki volatilite yayılımı negatif bulunmuş, buradan hareketle yatırımcıların bu dönemde altına yöneldikleri anlaşılmıştır. Bu iki yatırım aracı arasındaki en yüksek volatilite ise döviz kur hareketlerine paralel şekilde 2018 yılında gerçekleşmiştir. Pandemi sürecindeki volatilite ise ikinci en yüksek yayılım olarak tespit edilmiştir.

Bu çalışmaların yanında sınırlı sayıda da olsa katılım endeksi ise korona virüs arasındaki ilişkiyi inceleyen çalışmalar literatürde yer almaktadır. Şahbalı ve Kaya (2021) tarafında yapılan çalışmada, KATLM-50 endeksinin kapanış değerlerine en fazla etki eden değişkenler belirlenmeye çalışılmıştır. Altın fiyatı, Dolar ve Euro'dan oluşan döviz kuru sepeti, politika faizi ve korona virüs günlük vaka sayılarının bağımsız değişken olarak kullanıldığı çalışmada, katılım endeksine vaka sayıları ve altın fiyatlarının pozitif yönde etki ettiği sonucuna ulaşılmıştır. Erdoğan vd. (2020) çalışmalarında Covid -19 pandemisine geleneksel ve İ̉sâmi borsanın bulaşma ve ayrışma açısından gösterdiği tepkiyi incelemişlerdir. Çalışmada 10 Şubat 2011 - 02 Eylül 2020 dönemine ilişkin günlük veriler kullanılmış ve DCCGARCH yönteminden yararlanılmıştır. Bulgular sonucunda Covid -19 pandemisi şoku karşısında İslâmi borsa, geleneksel borsalara nazaran oynaklığın düşük olduğu dolayısıyla daha istikrarlı olarak tespit edilmiştir. Baykut ve Çonkar (2020) tarafından yapılan çalışmada ise, korona dönemini de kapsayan geniş bir veri seti ile konvansiyonel endeksler ile katılım endeksleri arasındaki nedensellik ve volatilite karşılaştırılmıştır. Çalışmadan elde edilen bulgulara göre, KATLM-30 endeksi, konvansiyonel endekslere göre daha düşük volatiliteye sahip olarak tespit edilmiştir. Literatür taramasında da görüleceği üzere, KATLM-30 Endeksi ile korona virüs üzerindeki ilişkiyi ele alan herhangi bir çalışmaya rastlanmamıştır. Bu durum, çalışmanın literatürdeki hangi boşluğu dolduracağı ve özgünlüğünün ne olacağı sorularına yanıt vermektedir. Çalışmanın izleyen bölümünde analizler yapılmış ve elde edilen bulgular yorumlanmıştır.

\section{ANALIZ VE BULGULAR}

Çalışmanın bu bölümünde, korona virüs verilerinin, Katılım-30 Endeksi üzerindeki etkileri analiz edilmiştir. Bu kapsamda Mart 2020-Aralık 2020 arasındaki döneme ilişkin günlük veriler kullanılarak analizler gerçekleştirilmiştir. Verilerin analize uygun hale getirilmesi için ilk önce veri uyumlaştırılması yapılmıştır. Katılım-30 Endeksi'ne ilişkin veriler sadece hafta içi günleri hesaplandığından dolayı, korona virüs verileri için de analizlerde sadece hafta içi rakamları kullanılmıştır. Katılım-30 (KATLM-30) Endeksi'ne ilişkin veriler, Türkiye Katılım Bankaları Birliği ve Bizim Menkul Değerler 'den temin edilmiş iken, korona virüs verileri ise T.C. Sağlık Bakanlığı veri tabanından elde edilmiştir. Katılım-30 Endeksi’nin ilgili dönemdeki getirilerine ilişkin veriler Şekil 1 yer almaktadır. Şekilde görüldüğü üzere Mart 2020 döneminde Katılım-30 Endeksi en düşük değerlere sahiptir. Şubat 2020'de elde edilen en yüksek değerden sonra yaşanan bu düşüş korona virüse bağlanabilir. Daha sonrasında korona virüs sürecinde yaşanan kontrol ve finansal piyasalardaki toparlanmanın etkisiyle, Katılım-30 Endeksi'nde yükseliş eğilimi başlamıştır. 


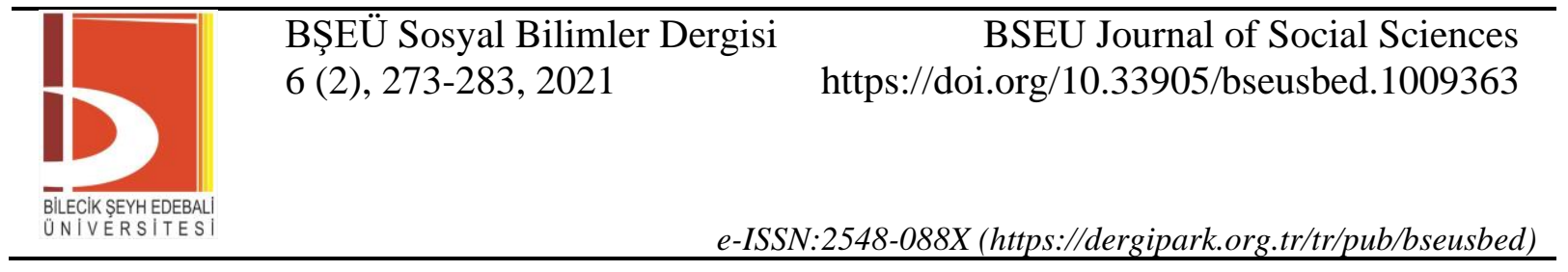

KATLM-30

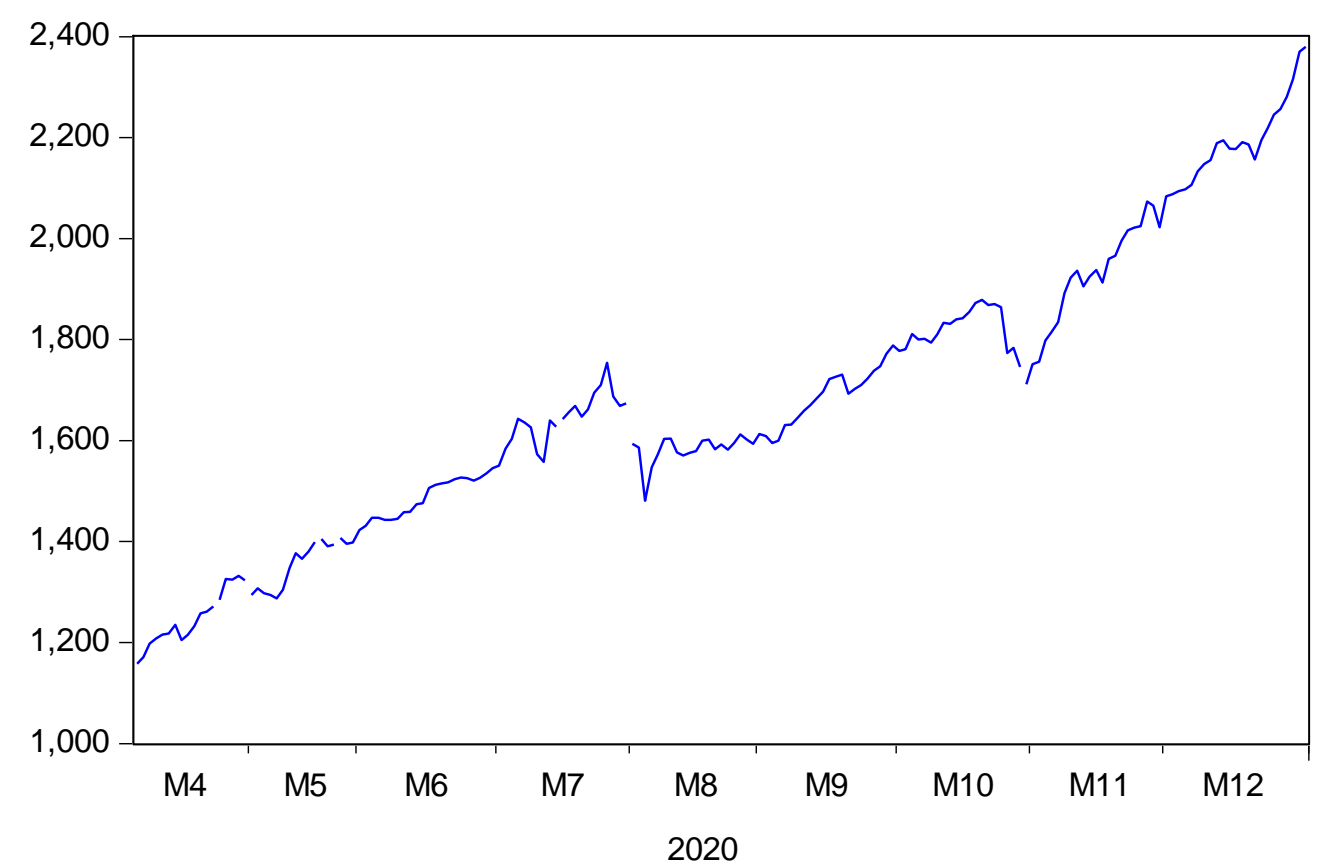

Şekil 1. Katılım-30 Endeksi Getiri Serisi

Yapılan veri uyumlaştırması sonucunda 11 Mart 2020- 31 Aralık 2020 arası dönemde analizlere dâhil edilen toplam 185 günlük gözlem serisi oluşturulmuştur. Korona virüs verileri 4 farklı başlık altında analiz kapsamına alınmıştır. Bunlar; günlük hasta sayısı, günlük vaka sayısı, günlük vefat sayısı ve günlük iyileşen hasta sayısı şeklindedir. Çalışmada kullanılan bu beş değişkene (KATLM-30, hasta sayısı, vaka sayısı, vefat sayısı ve iyileşen sayısı) ilişkin tanımlayıcı istatistikler Tablo 1'de yer almaktadır.

Tablo 1. Tanımlayıcı İstatistikler

\begin{tabular}{|l|c|c|c|c|c|}
\hline & KATLM-30 & VAKA & HASTA & VEFAT & IYILEŞEN \\
\hline Ortalama & 1678.627 & 10240.24 & 2345.173 & 77.48108 & 3917.497 \\
\hline Maksimum & 2379.900 & 32106 & 7381.000 & 259.0000 & 35511.00 \\
\hline Minimum & 1158.220 & 786.0000 & 786.0000 & 14.00000 & 256.0000 \\
\hline Standart Sapma & 281.7289 & 871.71 & 1632.465 & 68.94651 & 7437.064 \\
\hline Skewness & 0.387023 & 13.39720 & 1.490884 & 1.353819 & 3.254538 \\
\hline Kurtosis & 2.579535 & 181.3120 & 4.235106 & 3.818163 & 12.32010 \\
\hline Jarque-Bera & 5.981193 & 25021.8 & 80.29326 & 61.67205 & 996.1654 \\
\hline Olasilık & 0.050257 & 0.000000 & 0.000000 & 0.000000 & 0.000000 \\
\hline Gözlem & 185 & 185 & 185 & 185 & 185 \\
\hline
\end{tabular}

Tablo 1 incelendiğinde, her bir değişkenin 185 adet gözleme sahip olduğu ortaya çıkmaktadır. MartAralık 2020 arası dönemi kapsayan bu süreçte, KATLM-30 Endeksi’nin ortalama değeri 1678 olarak hesaplanırken, Türkiye'de ilk korona virüs vakasının tespit edilmesiyle beraber endeks değeri minimum değer olan 1158 'e kadar düşmüştür. Yine bu süre içerisinde korona virüs mücadelesindeki başarıya paralel olarak endekste toparlanma olmuş ve 2379 değerine kadar yükselmiştir. Bu dönemde korona virüs vakalarındaki seyre bakıldı̆̆ında günlük ortalama 10240 vaka sayısı tespit edilmiştir. En yüksek vaka tespiti 32106 iken en az vakanın tespit edildiği gün olarak ise 786 sayısına ulaşılmıştır. Benzer hesaplamalar hasta sayısı için de yapılmış ve 2345 ortalama sayısına ulaşılmıştır. Maksimum hasta sayısı 7381 iken minimum hasta sayısı 786 olmuştur. Günlük ortalama vefat sayısı ilgili dönemde 77 iken, iyileşen vaka sayısı ortalama 3917 olarak belirlenmiştir. Tanımlayıcı istatistiklerin belirlenmesinden sonra değişkenler arasındaki korelasyonun tespit edilmesi amacıyla korelasyon analizi yapılmıştır. Elde edilen sonuçlar Tablo 2'de raporlanmıştır. 
Tablo 2. Korelasyon Matrisi

\begin{tabular}{|c|c|c|c|c|c|}
\hline Değişken & KATLM-30 & HASTA & VAKA & VEFAT & İYILLEŞEN \\
\hline KATLM-30 & 1 & & & & \\
\hline HASTA & 0.44 & 1 & & & \\
\hline VAKA & 0.16 & 0.19 & 1 & & \\
\hline VEFAT & 0.68 & 0.78 & 0.20 & 1 & \\
\hline İYİLEŞEN & 0.58 & 0.31 & 0.07 & 0.76 & 1 \\
\hline
\end{tabular}

Tablo 2'deki sonuçlara göre, incelemeye konu olan 5 değişken arasında pozitif korelasyon mevcuttur. Korelasyon analizi sonucunda hasta sayısı ile vefat sayısı arasında nispeten daha kuvvetli pozitif bir ilişki mevcuttur. Bu sonuca göre, hasta sayısının artması vefat sayısındaki artışı ortaya çıkarmaktadır sonucunu ortaya çıkarabilir. Fakat daha isabetli çıkarımlar yapabilmek için ekonometrik modellerin uygulanması gerekmektedir. Birim kök testi sonucuna göre belirlenecek analiz tekniği için ARDL, Eş-Bütünleşme Testi veya nedensellik testleri olası teknikler olarak belirlenmiştir. Bu nedenle çalışma kapsamında, aşağıdaki denklem kurularak finansal ekonometrik analiz tekniklerinden uygun olan(lar)1 kullanılacaktır.

$$
K A T L M-30=f(H A S T A, V A K A, V E F A T, \dot{I} Y \dot{I} L E S ̧ E N)(\mathbf{1})
$$

KATLM-30 Endeksi'ne, korona virüs verilerinin etki edip etmediğinin tespiti amacıyla 1 nolu denklemde ifade edilen fonksiyonun analizi için 2 nolu denklem kullanılarak analizler gerçekleştirilecektir.

$$
K A T L M-30_{t}=\propto H A S T A_{t}+\beta V A K A_{t}+\delta V E F A T_{t}+\gamma \dot{\mathrm{I} Y} \dot{\mathrm{I}} L E S ̧ E N_{t}+u_{t}(\mathbf{2})
$$

2 numaralı denklemdeki modelin sınanması ve uygun ekonometrik modelin tespit edilmesi amaciyla ilk önce her bir değişkenin birim kök sınamamalarının yapılması gerekmektedir. Birim kök testlerinin yapılmasının amacı sahte regresyon sorununun önüne geçmek ve serilerin birim köke sahip olup olmadığının tespit edilmesidir. Bu kapsamda Dickey ve Fuller $(1979 ; 1981)$ tarafından önerilen Genelleştirilmiş Dickey Fuller (ADF) ve Phillips ve Perron (1988) tarafından geliştirilen Phillips-Perron (PP) testleri uygulanarak serilerin birim kök testleri analiz edilmiş ve sonuçları Tablo 3'de gösterilmiştir.

\begin{tabular}{|c|c|c|c|c|c|c|}
\hline \multirow{2}{*}{ Seriler } & \multicolumn{3}{|c|}{$A D F$} & \multicolumn{3}{|c|}{$P P$} \\
\hline & Düzey & Birinci Fark & Karar & Düzey & Birinci Fark & Karar \\
\hline KATLM-30 & $\begin{array}{l}-1.05 \\
(0.93)\end{array}$ & $\begin{array}{r}-13.50 \\
(0.00)\end{array}$ & & $\begin{array}{l}-1.05 \\
(0.93)\end{array}$ & $\begin{array}{c}-13.50 \\
(0.00)\end{array}$ & \\
\hline HASTA & $\begin{array}{l}-1.58 \\
(0.79) \\
\end{array}$ & $\begin{array}{r}-12.60 \\
(0.00)\end{array}$ & & $\begin{array}{l}-1,89 \\
(0.65)\end{array}$ & $\begin{array}{r}-12.83 \\
(0.00)\end{array}$ & \\
\hline$V A K A$ & $\begin{array}{l}-13.38 \\
(0.00)\end{array}$ & - & & $\begin{array}{c}-13.38 \\
(0.00)\end{array}$ & - & \\
\hline VEFAT & $\begin{array}{l}-0.30 \\
(0.98)\end{array}$ & $\begin{array}{r}-10.60 \\
(0.00)\end{array}$ & & $\begin{array}{l}-0.69 \\
(0.97)\end{array}$ & $\begin{array}{r}-11.28 \\
(0.00)\end{array}$ & \\
\hline IYYILEŞEN & $\begin{array}{l}-1.68 \\
(0.75)\end{array}$ & $\begin{array}{l}-6.37 \\
(0.00)\end{array}$ & $I(1)$ & $\begin{array}{l}-1.92 \\
(0.63)\end{array}$ & $\begin{array}{r}-13.08 \\
(0.00)\end{array}$ & $I(1)$ \\
\hline
\end{tabular}

Tablo 3. Birim Kök Testi Sonuçları

Açıklama: Parantez içinde verilen değerler olasılık değerleridir.

Tablo 3 'te yer alan sonuçlar incelendiğinde ADF ve PP birim kök testi uygulaması sonrasında, KATLM30, Hasta Sayısı, Vefat Sayısı ve İyileşen Sayısı değişkenlerinin tamamı düzeyde durağan değildir ve durağan hale gelmek için birinci farklarının alınması gerekmektedir. Dolayısıyla bu değişkenlere ilişkin birim kök testi sonucu I(1) 'dir. Günlük vaka sayısı değişkeni ise hem ADF hem de PP tekniğinde düzeyde durağan olduğundan birim kök testi sonucu $I(0)$ olarak belirlenmiştir. Bu sonuç, farklı mertebelerden durağanlığa sahip değişkenlerin arasındaki ilişkinin analizine imkân tanıyan ARDL/ Sınır Testi yaklaşımının kullanılmasını gerektirmektedir. ARDL/Sınır Testi yaklaşıma ilişkin yapılacak olan analizlerin ilk aşaması, modelin gecikme uzunluklarının belirlenmesidir. Akaike Bilgi Kriterine (AIC) göre, KATLM-30, hasta sayısı, vaka sayısı, vefat sayısı ve iyileşen sayısı değişkenleri için en uygun model ARDL (1,0,0,0,0)'dır. Bağımlı değişken olarak KATLM-30 Endeksi'nin kullanıldığı çalışmada, en ideal model olarak belirlenen ARDL $(1,0,0,0,0)$ modeline ilişkin katsayılar ve model varsayım istatistikleri Tablo 4'te verilmiştir. 
Tablo 4.ARDL (1,0,0,0, 0) Modeli Tahmin Sonuçları

\begin{tabular}{|c|c|c|c|c|}
\hline Değişken & Katsayl & Standart hata & t-istatistiği & Olasllik \\
\hline KATLM_30(-1) & 0.988349 & 0.008990 & 109.9394 & 0.0000 \\
\hline HASTA & -0.004762 & 0.002608 & -1.825840 & 0.0695 \\
\hline VAKA & $-1.06 \mathrm{E}-05$ & $2.08 \mathrm{E}-05$ & -0.510175 & 0.6106 \\
\hline VEFAT & 0.264968 & 0.096942 & 2.733265 & 0.0069 \\
\hline IYILESSEN & -0.001062 & 0.000538 & -1.973431 & 0.0500 \\
\hline C & 21.05676 & 13.86904 & 0.1307 \\
\hline Diagnostik (tanılama) testleri & \\
\hline Otokorelasyon - Breusch-Godfrey LM Testi $=1.197235(0.2843)$ & \\
\hline Değișen Varyans - Breusch-Pagan-Godfrey Testi $=1.8312943(0.7613)$ & \\
\hline JB Normallik Testi $=7.224897(0.049822)$ & \\
\hline
\end{tabular}

Tablo 4'te yer alan sonuçlara göre KATLM-30 değişkeninin, kendi bir dönem geçmiş değerlerinin yanında, hasta sayısı, vaka sayısı, vefat sayısı ve iyileşen sayısının mevcut dönem verileri, KATLM-30 Endeksi'ndeki değişimleri en iyi açıklayan modeldir. Bu modelden elde edilen sonuçları kullanarak sınır testi yaklaşımına geçmeden hemen önce bu modelin diagnostik testleri geçip geçmediği bir başka ifade ile bu modelin regresyon varsayımlarını sağlayıp sağlamadığı kontrol edilmiştir. Bu kapsamda, en uygun model olarak belirlenen ARDL $(1,0,0,0,0)$ modelinden elde edilen artık terimlerin birbiri ile ilişkili olup olmadığının tespiti için BreuschGodfrey LM Testi yapılmış ve elde edilen olasılık değerinin 0.28 olması artıkların ilişkisiz olduğunu ifade eden H0 (yokluk) hipotezinin reddedilemeyeceğini göstermiştir. Dolayısıyla artık terimler arasında otokorelasyon bulunmamaktadır. Yapılan bir değer tanılama testi artık terimlerin değişen varyansa sahip olup olmadığının tespiti üzerinedir. Breusch-Pagan-Godfrey Testi sonucunda elde edilen anlamlılık (olasılık) değerinin 0.76 olması, serilerin değişen varyansa sahip olmadığını göstermektedir. Yani serinin artık terimleri sabit bir varyansa sahiptir. $\mathrm{Bu}$ sınamalar sonucunda uygulanan modelin uygun olduğu ortaya çıkmış ve sınır testi yaklaşımına geçilerek sonuçlara ulaşılmıştır. En uygun model olarak belirlenen ARDL $(1,0,0,0,0)$ modeline uygulanan sınır testi sonuçları aşağıdaki Tablo 5 'te raporlanmıştır.

Tablo 5. Sinır Test Sonucu

\begin{tabular}{|c|c|c|c|c|}
\hline$k$ & $F_{-}$istatistiğ & Kritik Değerler & $I(0)$ & $I(1)$ \\
\hline \multirow{4}{*}{4} & \multirow{4}{*}{3.867266} & $\% 10$ & 2.2 & 3.09 \\
\hline & & $\% 5$ & 2.56 & 3.49 \\
\hline & & $\% 2.5$ & 2.88 & 3.87 \\
\hline & & $\% 1$ & 3.29 & 4.37 \\
\hline
\end{tabular}

Açıklama: $k$ modelde yer alan açıklayıcı değişkenlerin sayısını göstermektedir.

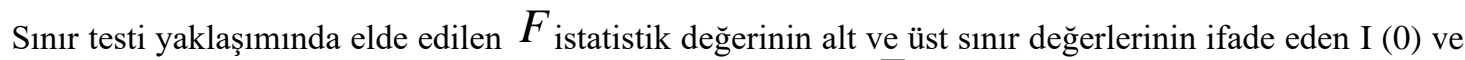
I (1) değerlerinin arasında olmaması gerekmektedir. Ĕger tespit edilen $F$ değeri \%1, \%2,5, \%5 ve \%10 anlamlılık düzeylerinde I (0) ve I (1) değerlerinin arasından kalır ise ilişkinin tam olarak tespit edilemeyeceği, I (0) değerinden küçük ise, ilişkinin olmadığı, I (1) değerinden büyük ise o anlamlılık düzeyinde istatistiksel olarak anlamlı olduğu sonucu ortaya çıkmaktadır. ARDL $(1,0,0,0,0)$ modeline uygulanan sınır testi sonucunda hesaplanan $F_{\text {istatistik }}$ değeri 3.867266'dır. Bu sonuç, \%1 anlamlılık düzeyinde değişkenler arasında tam olarak bir ilişkinin olduğunun tespit edilemeyeceğini bildirirken, \%2,5 anlamlılık düzeyinde ilişkinin olabileceğini fakat \%5 anlamlılık düzeyinde kesin olarak incelemeye konu olan değişkenler arasında uzun dönemli bir ilişkinin varlığını göstermektedir. \%5 anlamlılık düzeyinde I (1) değeri 3,49 olarak belirlenir iken, modelin $F$ istatistik değeri 3.86'dır yani I (1) değerinden yüksektir. Bu sonuç, korona virüs verilerinin uzun dönemde KATLM-30 Endeksi üzerinde etkili olduğunu göstermektedir. Elde edilen bu uzun dönem ilişkisine ait koentegrasyon denklemi aşağıdaki 3 nolu denklemde yer almaktadır: 
Koentegrasyon Denklemi $=$ KATLM-30- $(-0.4087 * H A S T A-0.0009 * V A K A+22.7417 * V E F A T-0.0911 *$ IYILESSEN + 1807.2588)

Değişkenler arasındaki uzun dönem ilişkisinin tespit edilmesinden sonra uzun dönem ilişkiyi gösteren tahmin katsayı değerleri Tablo 6'da gösterilmiştir. Tablo 6'ya göre, hasta sayısı değişkeninin uzun dönem katsayısı -0.40'tır. Dolayısıyla hasta sayısı ile KATLM-30 Endeksi arasında uzun dönemde negatif bir ilişki söz konusudur. Bu sonuç hasta sayısının artması ile KATLM-30 Endeksi'nde düşüşler yaşanabileceğinin açıklamasıdır. Özellikle Mart 2020'den itibaren hasta sayısındaki artışlar, endeksin düşmesinin açıklaması olarak kabul edilebilir. Benzer bir durum vaka sayısı ile de ortaya çıkmaktadır. Çalışma kapsamında kısa dönem katsayılarına ve hata düzeltme modeline de bakılmış fakat varsayımlar sağlanmadığı için raporlanmamıştır.

Tablo 6. Uzun Dönem Tahmin Katsayıları

\begin{tabular}{|c|c|c|c|c|}
\hline Dĕ̆ģsken & Katsayı & Standart hata & t-istatistiği & Olasılık \\
\hline HASTA & -0.408735 & 0.350418 & -1.166421 & 0.2450 \\
\hline VAKA & -0.000911 & 0.001946 & -0.468447 & 0.6400 \\
\hline VEFAT & 22.741661 & 16.388554 & 1.387655 & 0.1670 \\
\hline IYIILEŞEN & -0.091130 & 0.082214 & -1.108450 & 0.2692 \\
\hline C & 1807.258828 & 354.875791 & 5.092652 & 0.0000 \\
\hline
\end{tabular}

Çalışma kapsamında son olarak kurulan modelin stabil olup olmadığının tespiti için standartlaştırılmış rekursif kalıntılar için CUSUM (Cumulative Sum: Birikimli Toplam) ve CUSUMQ (Cumulative Sum Square: Birikimli Toplamlar Karesi)testleri yapılmıştır. Sonuçlar Şekil 1a ve Şekil 1b olarak aşağıda yer almaktadır. Bu sonuçlara göre, $\% 5$ anlamlılık düzeyinde, test istatistikleri belirlenen kritik değerler arasında yer aldığından, model uzun dönemde stabildir.

Şekil 2a-2b. CUSUM ve CUSUMSQ Testleri

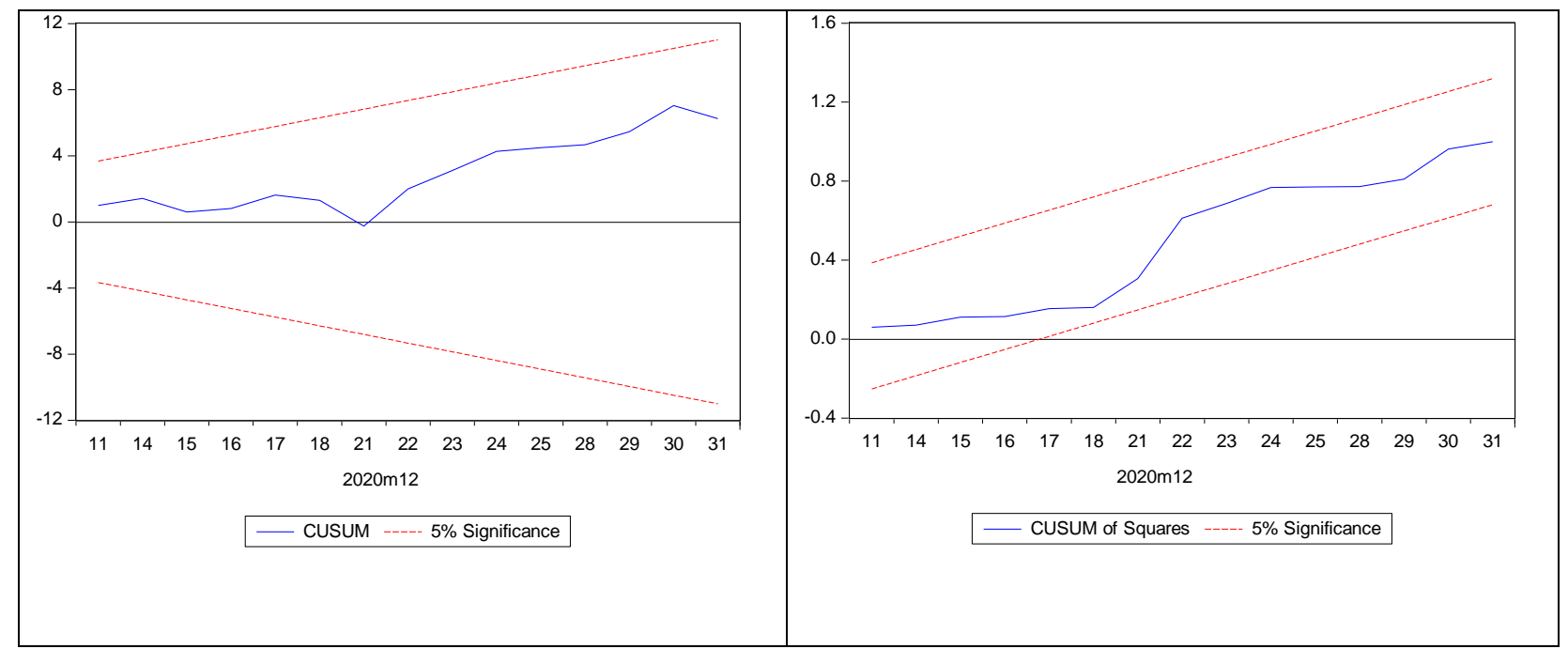

Genel olarak sonuçlar değerlendirildiğinde, korona virüsün hem geleneksel hem de İslami borsa endeksleri üzerinde önemli ölçüde etkileri olduğu ortaya çıkmaktadır. Bu çalışmada ARDL modelinin uygulanması sonucunda KATLM-30 Endeksi'ne uzun dönemde özellikle hasta sayısı ve vaka sayısının artışına bağlı olarak olumsuz olarak etkilenmektedir. Elde edilen bu sonuçlar yapısal kırılmaları dikkate alan QUSUM ve QUSUMQ analiz sonuçlarıyla da teyit edilmiştir.

\section{SONUÇLAR}

Korona virüsün finansal piyasalar üzerindeki etkisi özellikle Mart 2020'de olağanüstü düzeylere ulaşmıştır. Bu dönemde Avrupa Borsalarında yaşanan günlük \%12'ye varan düşüşler bu etkiyi net olarak ortaya koymuştur. Bu denli etkilerin en son 2008 Küresel Finans Krizi'nde görülmesi ve korona virüsün finansal piyasalar üzerindeki tahribatının Küresel Finans Krizi'nden daha yüksek olması, yatırımcıları daha dikkatli davranmaya 
itmiştir. Geleneksel hisse senedi piyasalarının yanında 2011 yılında hesaplanmaya başlanan Katılım Endeksleri de bu süreçten etkilenmişlerdir.

Katılım endekslerinde listelenen şirketlerin geleneksel endekslerden farklı olarak İslâmi faaliyet kriterlerini ve belirli finansal kriterleri sağlaması gerekmektedir. Bu finansal kriterler işletmelerin yüksek oranda kaldıraçlı işlem yapmasını engellemektedir. Buna bağlı olarak faizli işlemlerinin (kısıtlı olduğu ve/veya) olmadığ bu işletmelerin, korona virüs gibi küresel ölçekli olaylara karşı daha az duyarlı olması ve daha az etkilenmesi beklenmektedir. Bu çalışmada, Katılım-30 Endeksi ile korona virüs verileri arasındaki ilişki incelenmiştir. ARDL/Sınır testi yaklaşımı kullanılarak yapılan analizler neticesinde, Katılım-30 Endeksi ile korona virüs verileri arasında uzun dönemli ilişki tespit edilmiştir. Bu sonuç ayrıca CUSUM ve CUSUMQ testleriyle de teyit edilmiştir. Çalışma sonuçlarına göre, korona virüs süreci, Katılım-30 Endeksi'ni etkilemiştir.

Korona virüs tehlikesinin öngörülememesi ve olağandışı hızlı gelişen süreç, katılım endeksini oluşturan şirketlerin de bu durumdan derinden etkilenmelerine sebebiyet vermiştir. Kaldıraçlı işlemlerin yasak olduğu, faizli işlemlerden ziyade reel varlıklara dayalı sektör ve faaliyetlerin izlendiği endeksin finansal şoklara karşı hassas olduğu anlaşılmıştır. Bu sonuca bağlı olarak katılım finans sistemi içerisinde yer alan bu endekslerin geleneksel endekslerle benzer şekilde ani gelişen şoklara karşı zayıf olduğu söylenebilir. Daha önce yapılan çalışmalarda ise normal piyasa koşullarında katılım endekslerinin geleneksel endekslere göre daha iyi performans sergilediği teyit edilmiştir (Yıldırım \& Sakarya, 2019). Bu durum finansal şoklarda geçerliliğini kaybederek tüm endekslerde benzer davranışlara dönüşmektedir. İleriye yönelik olarak, tam normalleşme aşamasına geçilmesi sonrasında geleneksel endeksler ile katılım endeksleri performansları karşılaştırılarak performans farklılıkları tekrar test edilebilir. Bu tip bir çalışmayla hangi endeksin salgın sürecinden daha fazla etkilendiği üzerinde farklı kıyaslamalar ve değerlendirmeler yapılabilir.

\section{KAYNAKLAR}

Alber, N. (2020). The Effect of Coronavirus Spread on Stock Markets: The Case of the Worst 6 Countries. SSRN Electronic Journal, 1-11.

Albulescu, C. T. (2020). COVID-19 and the United States financial markets' volatility. Finance Research Letters, 1-5.

Alfaro, L., Chari, A., Greenland, A. N., \& Schott, P. K. (2020). Aggregate and Firm-Level Stock Returns During Pandemics, in Real Time. National Bureau of Economic Research, 1-31.

Ayittey, F. K., Ayittey, M. K., Chiwero, N. B., Kamasah, J. S., \& Dzuvor, C. (2020). Economic impacts of Wuhan 2019-nCoV on China and the world. Journal of Medical Virology, 92(5), 1-3.

Baek, S., K.Mohanty, S., \& Glambosky, M. (2020). COVID-19 and Stock Market Volatility: An Industry Level Analysis. Finance Research Letters(37), 1-10.

Baykut, E., \& Çonkar, K. (2020). BIST-30 ve KATLM-30 Endeksleri Arasındaki İlişkinin Değerlendirilmesi. Muhasebe ve Finans Incelemeleri Dergisi ,3(2) ,163 - 174.

Baker, S. R., Bloom, N., Davis, S. J., Kost, K. J., Sammon, M. C., \& Viratyosin, T. (2020). The Unprecedented Stock Market Impact of COVID-19. National Bureau os Economic Research - Working Paper 26945, 1-22.

Bizim Menkul Değerler (BMD) (2021). Katılım Endeks Kuralları. Katılım Endeksi: [Erişim: 08.10.2021,https://www.katilimendeksi.org/subpage/21/endeks_kurallari]

Çetin, A. C. (2020). Korona virüs (Covid-19) Salgınının Türkiye'de Genel Ekonomik Faaliyetlere ve Hisse Senedi Borsa Endeksine Etkisi. Mehmet Akif Ersoy Üniversitesi Uygulamall Bilimler Dergisi, 4(2), 341 362.

Çonkar, M., Canbaz, M. F., \& Öztürk, D. (2019). Katılım Endeksi ve Dünya İslami Endeksleri Normalarının Kıyaslanması. M. Çonkar, M. F. Canbaz, \& D. Öztürk içinde, International Congress Of Science Culture And Education Full Text Book (s. 563-575). Konya: Çizgi Kitabevi.

Deloitte (2020). Küresel Covid-19 Salgınının Türkiye'de Farklı Kategorilere Etkileri. İstanbul: Deloitte.

Eroğan, S., Gedikli, A., \& Çevik, E. İ. (2020). The Effects of the Covid-19 Pandemic on Conventional And Islamic Stock Markets In Turkey. Bilimname, 2020(42), 89-110. 
Kayral, İ. E., \& Tandoğan, N. Ş. (2020). BİST100, Döviz Kurları ve Altının Getiri ve Volatilitesinde COVID-19 Etkisi. Gaziantep Üniversitesi Sosyal Bilimler Dergisi(19), 687 - 701.

Keleş, E. (2020). Covıd-19 ve BİST-30 Endeksi Üzerine Kısa Dönemli Etkileri. Marmara Üniversitesi Íktisadi ve İdari Bilimler Dergisi, 42(1), 91-105.

Merkezi Kayıt Kuruluşu (MKK) (2020). Ylllık İstatistiki Veriler. Merkezi Kayıt Kuruluşu Web Sitesi:[Erişim: 23.11.2021, https://www.mkk.com.tr]

Morales, L., \& Andreosso-O'Callaghan, B. (2020). Covid-19 - Global Stock Markets "Black Swan". Critical Letters in Economics \& Finance(1), 1-14.

Özdemir, L. (2020). Covid-19 Pandemisinin BIST Sektör Endeksleri Üzerine Asimetrik Etkisi. Finans Ekonomi ve Sosyal Araştırmalar Dergisi, 5(3), 546-556.

Özkan, O. (2020). Oynaklık Sıçraması: COVID-19'un Türkiye Hisse Senedi Piyasası Üzerindeki Etkisi. Gaziantep Üniversitesi Sosyal Bilimler Dergisi, 387-397.

Sherif, M. (2020). The impact of Coronavirus (COVID-19) outbreak on faith-based investments: An original analysis. Journal of Behavioral and Experimental Finance(28), 1-9.

Şahbalı, S. N., \& Kaya, F. (2021). COVID-19 Salgın Hastalığının KAT50 Endeksine Etkisi: ARDL Sınır Testi Modeli. Avrasya Sosyal ve Ekonomi Araştırmaları Dergisi (ASEAD), 8(2), s. 38-50.

Yıldırım, H. H., \& Sakarya, Ş. (2019). BİST 30 ve Katılım 30 Endeksi Volatilitelerinin Karşılaştırılması. Muhasebe ve Finans İncelemeleri Dergisi, 2(2), 167 - 174. doi:10.32951/mufider.603460 